Situs Jurnal : $\underline{\text { http://ejurnal.stiepancasetia.ac.id/index.php/jieb }}$

Jilid 5 Nomor 1 Maret 2019

Hal $109-117$

\title{
PENGUKURAN KEPUASAN MASYARAKAT ATAS PELAYANAN PUBLIK DI KECAMATAN CEMPAKA KOTA BANJARBARU
}

\section{Eka Yulita Dewi*}

Abstract: This study aims to find out to find out the measurement of community satisfaction with public services in the Cempaka Subdistrict, Banjarbaru City based on the Community Satisfaction Index (IKM) and provide input for public services in the Cempaka Sub-District of Banjarbaru City that should be done. The data analysis technique used in this study is quantitative descriptive research by taking samples of 93 respondents and using questionnaires as the main data collection tool according to KEPMENPAN Number 14 of 2017. The results of the study can be concluded based on the calculation of the Community Satisfaction Index referring to the Minister of Administrative Reform and Bureaucratic Reform Number 14 of 2017, showing the performance of service units predicated "Good" with 82.00 IKM values covering 9 indicators based on Minister of Administrative Reform and Bureaucratic Reform Number 14 of 2017.

Keywords: community satisfaction, public services, Cempaka Subdistrict Banjarbaru City

Abstrak: Penelitian ini memiliki tujuan ingin mengetahui mengetahui pengukuran kepuasan masyarakat atas pelayanan publik di Kecamatan Cempaka Kota Banjarbaru berdasarkan Indeks Kepuasan Masyarakat (IKM) dan memberikan masukan pelayanan publik di Kecamatan Cempaka Kota Banjarbaru yang seharusnya dilakukan. Teknik analisa data yang digunakan dalam penelitian ini adalah penelitian deskriptif kuantitatif dengan mengambil sampel 93 responden dan menggunakan kuesioner sebagai alat pengumpulan data yang pokok sesuai KEPMENPAN Nomor 14 Tahun 2017. Hasil penelitian dapat disimpulkan berdasarkan perhitungan Indeks Kepuasan Masyarakat yang mengacu pada Peraturan Menteri Pendayagunaan Aparatur Negara dan Reformasi Birokrasi Nomor 14 Tahun 2017, maka menunjukan kinerja unit pelayanan berpredikat "Baik" dengan nilai IKM 82,00 meliputi 9 indikator berdasarkan Peraturan Menteri Pendayagunaan Aparatur Negara dan Reformasi Birokrasi Nomor 14 Tahun 2017.

Kata kunci : kepuasan masyarakat, pelayanan publik, Kecamatan Cempaka Kota Banjarbaru

\section{Latar Belakang}

Pelayanan publik sebagai penggerak utama juga dianggap penting oleh semua aktor dari unsur tata kelola pemerintahan. Para pejabat publik, unsur-unsur dalam masyarakat sipil dan dunia usaha sama-sama memiliki kepentingan terhadap perbaikan kinerja pelayanan publik. Ada tiga alasan penting yang melatar-belakangi bahwa pembaharuan pelayanan publik dapat mendorong praktik tata kelola pemerintahan di Indonesia. Pertama, perbaikan kinerja pelayanan publik dinilai penting oleh stakeholders, yaitu pemerintah, warga, dan sektor usaha. Kedua, pelayanan publik adalah ranah dari ketiga unsur governance melakukan interaksi yang sangat intensif. Ketiga, nilai-nilai yang selama ini mencirikan praktik good governance diterjemahkan secara lebih mudah dan nyata melalui pelayanan publik 
Fenomena pelayanan publik oleh birokrasi pemerintahan sarat dengan permasalahan, misalnya prosedur pelayanan yang berbelit-belit, ketidakpastian waktu dan harga yang menyebabkan pelayanan menjadi sulit dijangkau secara wajar oleh masyarakat. Hal ini menyebabkan terjadi ketidakpercayaan kepada pemberi pelayanan dalam hal ini birokrasi sehingga masyarakat mencari jalan alternatif untuk mendapatkan pelayanan melalui cara tertentu yaitu dengan memberikan biaya tambahan. Dalam pemberian pelayanan publik, disamping permasalahan diatas, juga tentang cara pelayanan yang diterima oleh masyarakat yang sering melecehkan martabatnya sebagai warga Negara. Masyarakat ditempatkan sebagai klien yang membutuhkan bantuan pejabat birokrasi, sehingga harus tunduk pada ketentuan birokrasi dan kemauan dari para pejabatnya. Hal ini terjadi karna budaya yang berkembang dalam birokrasi selama ini bukan budaya pelayanan, tetapi lebih mengarah kepada budaya kekuasaan.

Untuk mengatasi kondisi tersebut perlu dilakukan upaya perbaikan kualitas penyelenggaraan pelayanan publik yang berkesinambungan demi mewujudkan pelayanan publik yang prima sebab pelayanan publik merupakan fungsi utama pemerintah yang wajib diberikan sebaik-baiknya oleh pejabat publik. Salah satu upaya pemerintah adalah dengan melakukan penerapan prinsip-prinsip good governance atau tata kelola pemerintahan, yang diharapkan dapat memenuhi pelayanan yang prima terhadap masyarakat. Terwujudnya pelayanan publik yang berkualitas merupakan salah satu ciri good governance. Untuk itu, aparatur Negara diharapkan melaksanakan tugas dan tanggung jawabnya secara efektif dan efesien.

Pelayanan publik adalah kegiatan atau rangkaian kegiatan dalam rangka pemenuhan kebutuhan pelayanan sesuai peraturan perundang-undangan bagi setiap warga negara dan penduduk atas barang, jasa, atau pelayanan administratif yang disediakan oleh pemerintah. Berbagai pelayanan administratif, seperti Pelayanan Kartu Tanda Penduduk (KTP), Kartu Keluarga (KK), catatan perkawinan, surat keterangan pindah penduduk, akte kelahiran, akte kematian, sertifikasi tanah, dan perizinan, merupakan pelayanan yang diselenggarakan untuk menjamin hak dan kebtuhan dasar warga negara. Pelayanan KTP, KK, catatan perkawinan, surat keterangan pindah penduduk, akte kelahiran, dan akte kematian sangat vital dalam kehidupan warga karena keenamnya menjamin keberadaan, identitas warga dan hak-hak sipil lainnya. Pelayanan seperti itu tentu sangat penting dan menjadi bagian dari pelayanan publik yang harus diselenggarakan oleh Negara.

Aparat Camat sebagai bagian dari pegawai negeri dituntut untuk dapat menjadi motor penggerak pembangunan karena bersentuhan langsung dengan masyarakat sehingga akan lebih memahami keadaan dan kondisi masyarakat. Sebagai birokrat di tingkat Camat dituntut untuk mampu menangani kendala-kendala yang dihadapi dalam usaha-usaha pembangunan yang digalakkan pemerintah. Aparat Camat harus mampu melaksanakan fungsi utamanya yaitu memberikan pelayanan kepada masyarakat dengan baik, cekatan, efektif dan efisien. Sekretaris Camat dalam pelaksanaan tugasnya bertanggung jawab kepada Lurah, sekretaris Camat dibantu oleh beberapa orang staf. Kepala Lingkungan merupakan jabatan non struktural yang mempunyai tugas pokok membantu pelaksanaan tugas-tugas operasional Lurah dalam wilayah kerjanya.

Jenis-jenis pelayanan publik tersebut hanya sebagian dari banyaknya pelayanan publik yang diberikan pegawai kantor camat kepada masyarakat, karena sering ada program-program pemerintah yang biasanya diberikan kewenangan kepada kantor kecamatan untuk menanganinya, seperti misalnya program bantuan untuk masyarakat miskin. Para pegawai yang berada di kantor Camat bertugas mendistribusikan beras kepada masyarakat yang benar-benar membutuhkan. Selain itu, tugas dari pegawai pada kantor camat juga sering menangani surat- 
surat perijinan pendirian bangunan, surat-surat keterangan tidak mampu masyarakat yang membutuhkan untuk keringanan pengobatan, keringanan biaya pendidikan, yang semuanya itu menuntut pelayanan yang efektif agar masyarakat yang dilayani merasa puas. Pelayanan pegawai tergolong dalam jenis pelayanan publik karena adanya kepentingan umum dalam masyarakat yang dilayani Kepentingan umum yang ada di masyarakat merupakan sasaran utama dalam penyelenggaraan pelayanan publik. Pelayanan publik bukanlah suatu sasaran, melainkan suatu proses atau kegiatan untuk mencapai sasaran tertentu yang telah ditetapkan.

Tujuan penelitian ini adalah (1) Ingin mengetahui pengukuran kepuasan masyarakat atas pelayanan publik di Kecamatan Cempaka Kota Banjarbaru berdasarkan Indeks Kepuasan Masyarakat (IKM) dan (2) untuk memberikan masukan pelayanan publik di Kecamatan Cempaka Kota Banjarbaru yang seharusnya dilakukan.

\section{Kajian Literatur}

Pelayanan pada sektor swasta dengan pelayanan untuk instansi pemerintah memiliki indikator yang berbeda, mengingat tujuan dari pelayanan juga berbeda. Pada sektor swasta, pelayanan prima diberikan dengan tujuan untuk mendapatkan keunggulan bersaing. Indikator yang sering digunakan adalah kondisi fisik, kehandalan, kesigapan, jaminan dan keramahan. Kondisi fisik meliputi hal-hal yang berwujud seperti penampilan dan fasilitas yang mampu meningkatkan kualitas dari pelayanan yang diberikan. Kehandalan adalah ketepatan dalam pelayanan, kesigapan adalah kecepatan dalam memberikan pelayanan, jaminan adalah kepastian dalam pelayanan, dan keramahan adalah sikap dalam melayani.

Pelayanan untuk instansi pemerintah dikenal juga sebagai pelayanan publik. Wikipedia (2014:8) menggolongkan pelayanan publik sebagai segala bentuk jasa pelayanan, baik dalam bentuk barang publik maupun jasa publik yang pada prinsipnya menjadi tanggung jawab dan dilaksanakan oleh Instansi Pemerintah di Pusat, di Daerah, dan di lingkungan Badan Usaha Milik Negara atau Badan Usaha Milik Daerah, dalam rangka upaya pemenuhan kebutuhan masyarakat maupun dalam rangka pelaksanaan ketentuan peraturan perundang-undangan. Sianipar (2014:99) menjelaskan bahwa pelayanan publik adalah segala sesuatu bentuk pelayanan sektor publik yang dilaksanakan aparatur pemerintah dalam bentuk barang dan jasa, yang sesuai dengan kebutuhan masyarakat dan ketentuan perundangan yang berlaku. Widodo (2013:11) mengartikan pelayanan publik sebagai pemberian layanan keperluan masyarakat yang mempunyai kepentingan pada orang itu sesuai dengan aturan pokok dan tata cara yang telah ditetapkan. Lebih jauh lagi. Widodo (2013:13) menyatakan bahwa dalam upaya menciptakan kualitas layanan yang baik, maka dalam memberikan layanan publik seharusnya:

1. Mudah dalam pengurusan bagi yang berkepentingan.

2. Mendapat pelayanan yang wajar.

3. Mendapat pelayanan yang sama tanpa pilih kasih.

4. Mendapat perlakuan yang jujur dan transparan.

Dari serangkaian penjelasan yang telah dijabarkan, dapat disimpulkan bahwa pelayanan publik adalah upaya pemenuhan kebutuhan masyarakat oleh aparatur pemerintah dengan menggunakan standar perundangan yang berlaku.

Seiring dengan kemajuan teknologi dan tuntutan masyarakat dalam hal pelayanan, maka unit penyelenggara pelayanan publik dituntut untuk memenuhi harapan masyarakat dalam melakukan pelayanan. Pelayanan publik yang dilakukan oleh aparatur pemerintah saat ini dirasakan belum memenuhi harapan masyarakat. Hal ini dapat diketahui dari berbagai keluhan masyarakat yang disampaikan melalui media massa dan jejaring sosial. Tentunya keluhan tersebut, jika tidak ditangani memberikan dampak buruk terhadap pemerintah. Lebih jauh lagi 
adalah dapat menimbulkan ketidakpercayaan dari masyarakat. Salah satu upaya yang harus dilakukan dalam perbaikan pelayanan publik adalah melakukan survei kepuasan masyarakat kepada pengguna layanan dengan mengukur kepuasan masyarakat pengguna layanan.

Mengingat unit layanan publik sangat beragam, untuk memperoleh Indeks Pelayanan Publik secara nasional maka dalam melakukan Survei Kepuasan Masyarakat diperlukan metode survei yang seragam sebagaimana diatur didalam pedoman ini.

Selama ini, dalam melakukan survei kepuasan masyarakat menggunakan Peraturan Menteri Nomor 16 Tahun 2014 tentang Pedoman Survei Kepuasan Masyarakat Terhadap Penyelenggaraan Pelayanan Publik. Peraturan ini dipandang tidak operasional dan memerlukan penjabaran teknis dalam pelaksanaannya. Oleh karena itu, Peraturan ini dipandang perlu untuk disesuaikan dengan metode survei yang aplikatif dan mudah untuk dilaksanakan. Selain itu, Peraturan ini dimaksudkan untuk memberikan arahan dan pedoman yang jelas dan tegas bagi penyelenggara pelayanan publik.

Peraturan ini bertujuan untuk mengukur tingkat kepuasan masyarakat sebagai pengguna layanan dan meningkatkan kualitas penyelenggaraan pelayanan publik.

1. Mendorong partisipasi masyarakat sebagai pengguna layanan dalam menilai kinerja penyelenggara pelayanan.

2. Mendorong penyelenggara pelayanan untuk meningkatkan kualitas pelayanan publik.

3. Mendorong penyelenggara pelayanan menjadi lebih inovatif dalam menyelenggarakan pelayanan publik.

4. Mengukur kecenderungan tingkat kepuasan masyarakat terhadap pelayanan publik.

Dalam melaksanakan survei kepuasan masyarakat, dilakukan dengan memperhatikan prinsip:

1. Transparan

Hasil survei kepuasan masyarakat harus dipublikasikan dan mudah diakses oleh seluruh masyarakat.

2. Partisipatif

Dalam melaksanaan Survei Kepuasan Masyarakat harus melibatkan peran serta masyarakat dan pihak terkait lainnya untuk mendapatkan hasil survei yang sebenarnya.

3. Akuntabel

Hal-hal yang diatur dalam Survei Kepuasan Masyarakat harus dapat dilaksanakan dan dipertanggungjawabkan secara benar dan konsisten kepada pihak yang berkepentingan berdasarkan kaidah umum yang berlaku.

4. Berkesinambungan

Survei Kepuasan Masyarakat harus dilakukan secara berkala dan berkelanjutan untuk mengetahui perkembangan peningkatan kualitas pelayanan.

5. Keadilan

Pelaksanaan Survei Kepuasan Masyarakat harus menjangkau semua pengguna layanan tanpa membedakan status ekonomi, budaya, agama, golongan dan lokasi geografis serta perbedaan kapabilitas fisik dan mental.

6. Netralitas

Dalam melakukan Survei Kepuasan Masyarakat, surveyor tidak boleh mempunyai kepentingan pribadi, golongan, dan tidak berpihak.

Ruang lingkup Pedoman Penyusunan SKM Penyelenggara Pelayanan Publik pada Peraturan ini, meliputi Metode Survei, Pelaksanaan dan Teknik Survei, Langkah-Langkah Penyusunan Survei Kepuasan Masyarakat, Langkah-Langkah Pengolahan Data, Pemantauan, 
Evaluasi dan Mekanisme Pelaporan Hasil Penilaian Indeks Survei Kepuasan Masyarakat, Analisa Hasil Survei dan Rencana Tindak Lanjut. Unsur Standar Kepuasan Masyarakat (SKM) terdiri dari:

\section{Persyaratan}

Persyaratan adalah syarat yang harus dipenuhi dalam pengurusan suatu jenis pelayanan, baik persyaratan teknis maupun administratif.

2. Sistem, Mekanisme, dan Prosedur

Prosedur adalah tata cara pelayanan yang dibakukan bagi pemberi dan penerima pelayanan, termasuk pengaduan.

3. Waktu Penyelesaian

Waktu Penyelesaian adalah jangka waktu yang diperlukan untuk menyelesaikan seluruh proses pelayanan dari setiap jenis pelayanan.

4. Biaya/Tarif

Biaya/Tarif adalah ongkos yang dikenakan kepada penerima layanan dalam mengurus dan/atau memperoleh pelayanan dari penyelenggara yang besarnya ditetapkan berdasarkan kesepakatan antara penyelenggara dan masyarakat.

5. Produk Spesifikasi Jenis Pelayanan

Produk spesifikasi jenis pelayanan adalah hasil pelayanan yang diberikan dan diterima sesuai dengan ketentuan yang telah ditetapkan. Produk pelayanan ini merupakan hasil dari setiap spesifikasi jenis pelayanan.

6. Kompetensi Pelaksana

Kompetensi Pelaksana adalah kemampuan yang harus dimiliki oleh pelaksana meliputi pengetahuan, keahlian, keterampilan, dan pengalaman.

7. Perilaku Pelaksana

Perilaku Pelaksana adalah sikap petugas dalam memberikan pelayanan.

8. Penanganan Pengaduan, Saran dan Masukan

Penanganan pengaduan, saran dan masukan, adalah tata cara pelaksanaan penanganan pengaduan dan tindak lanjut.

9. Sarana dan prasarana

Sarana adalah segala sesuatu yang dapat dipakai sebagai alat dalam mencapai maksud dan tujuan. Prasarana adalah segala sesuatu yang merupakan penunjang utama terselenggaranya suatu proses (usaha, pembangunan, proyek). Sarana digunakan untuk benda yang bergerak (komputer, mesin) dan prasarana untuk benda yang tidak bergerak (gedung).

\section{Metode Penelitian}

Jenis rancangan penelitian merupakan suatu rencana kegiatan yang dibuat oleh peneliti untuk memecahkan masalah, sehingga akan diperoleh data yang sesuai dengan tujuan penelitian. Penelitian mengenai pengukuran kepuasan masyarakat atas pelayanan publik di Kecamatan Cempaka Kota Banjarbaru merupakan penelitian deskriptif kuantitatif, metode ini bertujuan untuk menggambarkan sifat sesuatu yang tengah berlangsung pada saat penelitian dilakukan. Penelitian deskriptif kuantitatif ini mengambil sampel dari satu populasi dan menggunakan kuesioner sebagai alat pengumpulan data yang pokok.

Populasi adalah wilayah generalisasi yang terdiri atas objek atau subjek yang mempunyai kualitas dan karakteristik tertentu yang ditetapkan oleh peneliti untuk dipelajari dan kemudian ditarik kesimpulannya. Populasi pada penelitian ini merupakan masyarakat/warga Kecamatan Cempaka Kota Banjarbaru sebanyak 1.294 orang selama tahun 2018. Pengambilan sampel dalam penelitian ini menggunakan metode rumus Slovin, sehingga dapat diperoleh besaran sampel penelitian ini adalah 93 orang. 
Teknik yang digunakan peneliti dalam menganalisis yang telah diperoleh melalui observasi, interview, dan dokumentasi adalah teknik analisis deskriptif kuantitatif. Teknik analisis ini dilakukan dengan survei kepada masyarakat Kecamatan Cempaka Kota Banjarbaru, dimana survei ini dilakukan dengan penyebaran kuesioner kepada para masyarakat Kecamatan Cempaka Kota Banjarbaru. Dimana pertanyaan atau parameter yang akan diukur sebagai berikut:

Bobot Nilai Rata-Rata Tertimbang $=-\frac{\text { Jumlah Bobot }}{\text { Jumlah Unsur }}=\frac{1}{9}=0,1$

Untuk memperoleh nilai Indeks Kepuasan Masyarakat (IKM) dipergunakan rumus sebagai berikut:

\section{Total dari Persepsi Nilai Per Unsur X Nilai Penimbang Total Unsur Yang Terisi}

Guna mempermudah interpretasi nilai IKM yang berkisar 25-100, maka hasil penilaian masingmasing dikalikan 25 .

Nilai IKM Unit Pelayanan X 25

Hasil perhitungan tersebut diatas dikategorikan seperti ditunjukkan pada Tabel 1.

Tabel 1. Nilai Persepsi, Interval IKM, Interval Konversi IKM

\begin{tabular}{lllll}
\hline $\begin{array}{l}\text { Nilai } \\
\text { Persepsi }\end{array}$ & Interval & $\begin{array}{l}\text { Interval } \\
\text { Konversi }\end{array}$ & $\begin{array}{l}\text { Mutu } \\
\text { Pelayanan }\end{array}$ & $\begin{array}{l}\text { Kinerja } \\
\text { Unit Pelayanan }\end{array}$ \\
\hline 1 & $1,00-2,59$ & $25,00-64,99$ & D & Tidak Baik \\
\hline 2 & $2,60-3,06$ & $65,00-76,60$ & C & Kurang Baik \\
\hline 3 & $3,07-3,53$ & $76,61-88,30$ & B & Baik \\
\hline 4 & $3.54-4,00$ & $88,31-100,00$ & A & Sangat Baik \\
\hline
\end{tabular}

Sumber : Permenpan RB No. 14/2017

\section{Hasil Penelitian dan Pembahasan}

Pengukuran kualitas pelayanan berdasarkan Peraturan Menteri Pendayagunaan Aparatur Negara dan Reformasi Birokrasi Nomor 14 Tahun 2017 terhadap pelayanan publik yang diberikan Kantor Kecamatan Cempaka Kota Banjarbaru dari 9 indikator digunakan untuk mengetahui tanggapan masyarakat pengguna layanan ini akan pelayanan yang telah diberikan kepadanya. Indeks ini digunakan sebagai tolak ukur dari kualitas pelayanan umum di Kantor Kecamatan Cempaka Kota Banjarbaru dalam memenuhi standar pelayanan minimal yang diisyaratkan oleh pemerintah. Untuk menentukan kinerja setiap unsur adalah Nilai IKM setelah dikonversi $=$ Nilai Indeks $\mathrm{X}$ Nilai Dasar $=$ Kinerja Unit Pelayanan yang masing-masing indikator akan dilakukan tabulasi data untuk mendapatkan frekuensi dan prosentase setiap unit pelayanan. Maka akan diuraikan hasil tanggapan terhadap kepuasan masyarakat pada Kecamatan Cempaka Kota Banjarbaru seperti ditunjukkan pada Tabel 2. 
Tabel 2. Rekapitulisasi Tanggapan Responden Terhadap Kepuasan Masyarakat Atas Pelayanan Publik di Kecamatan Cempaka Kota Banjarbaru

\begin{tabular}{|c|c|c|c|c|c|c|}
\hline \multirow[t]{2}{*}{ Uraian } & \multicolumn{4}{|c|}{ Point (Nilai) } & \multirow[t]{2}{*}{ Skor } & \multirow[t]{2}{*}{ NRR /Unsur } \\
\hline & 4 & 3 & 2 & 1 & & \\
\hline Persyaratan & 55 & 23 & 13 & 2 & 317 & 3,41 \\
\hline Sistem, Mekanisme, dan Prosedur & 52 & 26 & 14 & 1 & 315 & 3,39 \\
\hline Waktu Penyelesaian & 51 & 23 & 14 & 5 & 306 & 3,29 \\
\hline Biaya/Tarif & 50 & 22 & 18 & 3 & 305 & 3,28 \\
\hline Produk Spesifikasi Jenis Pelayanan & 52 & 29 & 9 & 3 & 316 & 3,40 \\
\hline Kompetensi Pelaksana & 47 & 22 & 18 & 6 & 296 & 3,18 \\
\hline Perilaku Pelaksana & 49 & 23 & 13 & 8 & 299 & 3,22 \\
\hline $\begin{array}{l}\text { Penanganan Pengaduan, Saran dan } \\
\text { Masukan }\end{array}$ & 46 & 25 & 19 & 3 & 300 & 3,23 \\
\hline Sarana dan Prasarana & 44 & 25 & 15 & 9 & 290 & 3,12 \\
\hline
\end{tabular}

Keterangan:

Skor $=(4 *$ tanggapan $)+(3 *$ tanggapan $)+(2 *$ tanggapan $)+(1 *$ tanggapan $)$

NRR/Unsur $=$ Jumlah Skor/Jumlah Sampel (Responden)

Menyikapi Tabel 2 dapat diinterpretasikan bahwa dari hasil tabulasi data 93 responden, maka didapatkan bahwa terdapat 55 responden memberikan jawaban sangat sesuai dengan point (nilai) 4, 23 responden memberikan jawaban sesuai dengan point (nilai) 3, 13 responden memberikan jawaban kurang sesuai dengan point (nilai) 2, dan 2 responden memberikan jawaban tidak sesuai dengan point (nilai) 1 terhadap unsur persyaratan pada Kecamatan Cempaka Kota Banjarbaru dengan nilai rata-rata (NRR) per unsur sebesar 3,41 kategori Baik.

Pada unsur sistem, mekanisme dan prosedur (Tabel 4.8) pada Kecamatan Cempaka Kota Banjarbaru dari 93 responden terdapat 52 responden memberikan jawaban sangat mudah dengan point (nilai) 4, 26 responden memberikan jawaban mudah dengan point (nilai) 3, 14 responden memberikan jawaban kurang mudah dengan point (nilai) 2, dan 1 responden memberikan jawaban tidak mudah dengan point (nilai) 1 dengan nilai rata-rata (NRR) per unsur sebesar 3,39 kategori Baik.

Pada unsur waktu penyelesaian (Tabel 4.8) pada Kecamatan Cempaka Kota Banjarbaru dari 93 responden terdapat 51 responden memberikan jawaban sangat cepat dengan point (nilai) 4, 26 responden memberikan jawaban cepat dengan point (nilai) 3,14 responden memberikan jawaban kurang cepat dengan point (nilai) 2, dan 1 responden memberikan jawaban tidak cepat dengan point (nilai) 1 dengan nilai rata-rata (NRR) per unsur sebesar 3,29 kategori Baik.

Pada unsur biaya/tarif (Tabel 4.8) pada Kecamatan Cempaka Kota Banjarbaru dari 93 responden terdapat 50 responden memberikan jawaban sangat mahal dengan point (nilai) 4, 22 responden memberikan jawaban cukup mahal dengan point (nilai) 3, 18 responden memberikan jawaban kurang murah dengan point (nilai) 2, dan 3 responden memberikan jawaban gratis dengan point (nilai) 1 dengan nilai rata-rata (NRR) per unsur sebesar 3,28 kategori Baik.

Pada unsur produk spesifikasi jenis pelayanan (Tabel 4.8) pada Kecamatan Cempaka Kota Banjarbaru dari 93 responden terdapat 52 responden memberikan jawaban sangat sesuai dengan point (nilai) 4, 29 responden memberikan jawaban sesuai dengan point (nilai) 3,9 responden memberikan jawaban kurang sesuai dengan point (nilai) 2, dan 3 responden memberikan jawaban tidak sesuai dengan point (nilai) 1 dengan nilai rata-rata (NRR) per unsur sebesar 3,40 kategori Baik. 
Pada unsur kompetensi pelaksana (Tabel 4.8) pada Kecamatan Cempaka Kota Banjarbaru dari 93 responden terdapat 47 responden memberikan jawaban sangat kompeten dengan point (nilai) 4, 22 responden memberikan jawaban kompeten dengan point (nilai) 3, 18 responden memberikan jawaban kurang kompeten dengan point (nilai) 2, dan 6 responden memberikan jawaban tidak kompeten dengan point (nilai) 1 dengan nilai rata-rata (NRR) per unsur sebesar 3,18 kategori Baik.

Pada unsur perilaku pelaksana (Tabel 4.8) pada Kecamatan Cempaka Kota Banjarbaru dari 93 responden terdapat 49 responden memberikan jawaban sangat sopan dan ramah dengan point (nilai) 4, 23 responden memberikan jawaban sopan dan ramah dengan point (nilai) 3, 13 responden memberikan jawaban kurang sopan dan ramah dengan point (nilai) 2, dan 8 responden memberikan jawaban tidak sopan dan ramah dengan point (nilai) 1 dengan nilai ratarata (NRR) per unsur sebesar 3,22 kategori Baik.

Pada unsur penanganan pengaduan, saran dan masukan (Tabel 4.8) pada Kecamatan Cempaka Kota Banjarbaru dari 93 responden terdapat 46 responden memberikan jawaban dikelola dengan baik dengan point (nilai) 4, 25 responden memberikan jawaban berungsi kurang maksimal dengan point (nilai) 3,19 responden memberikan jawaban ada tetapi tidak berfungsi dengan point (nilai) 2, dan 3 responden memberikan jawaban tidak ada dengan point (nilai) 1 dengan nilai rata-rata (NRR) per unsur sebesar 3,23 kategori Baik.

Pada unsur sarana dan prasarana (Tabel 4.8) pada Kecamatan Cempaka Kota Banjarbaru dari 93 responden terdapat 44 responden memberikan jawaban sangat baik dengan point (nilai) 4, 25 responden memberikan jawaban baik dengan point (nilai) 3, 15 responden memberikan jawaban cukup dengan point (nilai) 2, dan 9 responden memberikan jawaban buruk dengan point (nilai) 1 dengan nilai rata-rata (NRR) per unsur sebesar 3,12 kategori Baik.

Saran operasional yang dapat dijalankan oleh Kantor Kecamatan Cempaka Kota Banjarbaru dalam kualitas pelayanan agar masyarakat dapat nyaman dan tidak memberikan keluhan terhadap Kantor Kecamatan Cempaka Kota Banjarbaru meliputi memberikan bekal pendidikan dan pelatihan bagi para pegawainya untuk dapat memaksimalkan kepada masyarakat misalnya cara berkomunikasi, cara menghadapi masyarakat dengan baik dan lainlain. Pemberian sanksi kepada pegawai Kantor Kecamatan Cempaka Kota Banjarbaru jika ketahuan melakukan pungutan terhadap pelayanan yang diberikan kepada masyarakat serta melibatkan seluruh aspek masyarakat baik tokoh masyarakat, RT, RW maupun Kelurahan untuk kemajuan Kantor Kecamatan Cempaka Kota Banjarbaru dalam memberikan saran pembangunan bagi pelayanan yang lebih baik lagi.

Untuk dapat memberikan kepastian, meningkatkan kualitas dan kinerja pelayanan sesuai dengan kebutuhan masyarakat Kecamatan Cempaka Kota Banjarbaru dan selaras dengan kemampuan penyelenggara sehingga mendapatkan kepercayaan masyarakat hendaknya pula Kantor Kecamatan Cempaka Kota Banjarbaru dalam menciptakan kualitas layanan yang baik, maka dalam memberikan layanan publik kepada masyarakatnya seharusnya mudah dalam pengurusan bagi yang berkepentingan, mendapat pelayanan yang wajar, mendapat pelayanan yang sama tanpa pilih kasih dan mendapat perlakuan yang jujur dan transparan.

\section{Kesimpulan}

Berdasarkan perhitungan Indeks Kepuasan Masyarakat yang mengacu pada Peraturan Menteri Pendayagunaan Aparatur Negara dan Reformasi Birokrasi Nomor 14 Tahun 2017, maka diperoleh angka indeks sebesar 82,00 yang berada pada interval 76,61-88,30, sehingga pengukuran kepuasan masyarakat atas pelayanan publik di Kantor Kecamatan Cempaka Kota Banjarbaru berada pada tingkat "B". Hal ini menunjukkan bahwa kinerja pelayanan Kantor Kecamatan Cempaka Kota Banjarbaru secara keseluruhan termasuk dalam kategori baik. 
Kualitas pelayanan yang seharusnya diberikan Kantor Kecamatan Cempaka Kota Banjarbaru meliputi persyaratan pelayanan yang dijalankan dapat diinformasikan secara terbuka, alur/proses pelayanan tidak membingungkan masyarakat dan tidak terbelit-belit, adanya pegawai yang selalu standby, menerapkan kualitas pelayanan yang tidak memungut biaya sepeser pun, hasil produk pelayanan yang diterima oleh masyarakat agar dapat melakukan pengecekan, membekali pegawai yang ada dengan pendidikan dan pelatihan, pegawai Kantor Kecamatan Cempaka Kota Banjarbaru dapat memberikan pelayanan dengan tutur kata yang sopan, sikap ramah, penempatan kotak saran masukan agar ditempatkan yang strategis serta memberikan kenyamanan terhadap masyarakat dari sarana dan prasarana yang ada di Kantor Kecamatan Cempaka Kota Banjarbaru.

Saran penelitian ini meliputi (1) Pelayanan Kantor Kecamatan Cempaka Kota Banjarbaru tergolong kurang baik. Untuk kedepan maka, pelayanan yang diberikan minimal lebih untuk ditingkatkan agar menjadi lebih baik lagi dengan menunjukkan daftar biaya pelayanan kepada masyarakat secara jelas dan transparansi, menambah jumlah petugas pelayanan agar proses pelayanan semakin baik dan cepat serta memberikan bekal pelatihan untuk meningkatkan kepuasan masyarakat serta jangka waktu pelayanan yang diberikan kepada masyarakat hendaknya diupayakan untuk lebih baik dan lebih cepat dibandingkan dengan standar waktu pelayanan yang telah ditentukan. (2) Kantor Kecamatan Cempaka Kota Banjarbaru perlu memberikan informasi pelayanan yang jelas kepada setiap masyarakat. Contohnya menunjukkan papan informasi mengenai prosedur, persyaratan, biaya, dan waktu pelayanan pada setiap jenis pelayanan yang dapat dilihat secara langsung oleh masyarakat.

\section{DAFTAR PUSTAKA}

Komaruddin, Muhammad, 2014, Analisis dan Penerapannya, Penerbit Raja Grafindo, Jakarta Kotler, Philip dan Kevin Lane Keller, 2009, Manajemen Pemasaran, Edisi 13, Jilid Satu, Penerbit Erlangga, Jakarta

Lupiyoadi, Rambat, 2013, Manajemen Pemasaran Jasa : Teori dan Pratek, Salemba Empat, Jakarta

Nasution, M. Nur, 2013, Manajemen Jasa Terpadu, Ghalia Indonesia, Bogor

Othman dan Owen, 2013, Analisis Model Carter, Ghalia Indonesia, Bogor

Parasuraman, dkk, 2015, Manajemen Pemasaran Jasa Di Indonesia, Analisis Perencanaan, Implementasi dan Pengendalian (Edisi pertama). Salemba Empat, Jakarta

Rangkuti, Freddy, 2012, Measuring Customer Satisfaction (cetakan ketiga), PT.Gramedia Pustaka Utama, Jakarta

Saladin, Djaslim, 2012, Bauran Pemasaran dan Loyalitas Konsumen, Cetakan Ketiga, Penerbit Alfabeta, Bandung

Sunarto, 2013, Manajemen Pemasaran Dalam Konsep, Edisi Kelima, Penerbit Erlangga, Jakarta Tjiptono, Fandy, 2012, Strategi Pemasaran (Edisi II), Penerbit Andi, Yogyakarta

Umar, Husen, 2015, Statistik dan Metodelogi Penelitian, Pusaka Baru, Jakarta 